\title{
ONLINE PRICING FOR SMALL MEDIUM ENTERPRISES' PRODUCTS IN THE EX-LOCALIZATION OF DOLLY SURABAYA
}

\author{
Ig. Jaka Mulyana ${ }^{1}$, Ivan Gunawan ${ }^{1 *}$, Dian Trihastuti ${ }^{1}$, Yehezkiel Prakoso Putra \\ Yunen $^{1}$, Dwi Agustin Nuriani Sirodj ${ }^{2}$ \\ ${ }^{1}$ Department of Industrial Engineering, Faculty of Technology, Universitas Katolik Widya Mandala \\ Surabaya, \\ J1. Kalijudan No. 37, Kampus WM Kalijudan, Surabaya, Indonesia 60114 \\ ${ }^{2}$ Department of Statistics, Faculty of Mathematics and Natural Science, Universitas Islam Bandung, \\ Jl. Ranggagading No. 8, Bandung, Indonesia 40116
}

\begin{abstract}
Numerous Small and Medium Enterprises (SMEs) do not have a basic method in pricing decisions. Many times, this decision comes up based on an intuitive probe instead of a detailed analysis. This could lead to marketing problems, which may result in disruptions of financial liquidity. This also applies to SMEs wishing to sell products through the online channel. They need a proper pricing strategy, considering its different marketing strategies. Sales made through both offline channels (conventional stores) and online channels are known as Dual-Channel Supply Chain (DCSC). It is argued that the pricing decision at DCSC needs to consider consumer preferences in selecting the sales channel. One assumption commonly adopted in the DCSC pricing model is that the lost value if consumers purchase products through online channels. Therefore, the pricing decision for the online channel should be cheaper than the price on the offline channel. This study aims to assist SMEs in the ex-localization of Dolly in Surabaya in determining the price of products to be sold through online channels. Three types of products: batik, chips, and leather shoes were selected as research samples to represent the product groups: craft, fashion, and processed food. This study proposes an optimal online price strategy through experiments with a mathematical model. Model parameters, namely consumer preferences in choosing sales channels, are obtained through surveys. Apart from that, surveys are also used to reveal which platforms consumers are interested in shopping online. Shopee and Instagram were chosen by respondents as the most popular marketplaces and social media for online shopping. Finally, the online prices proposed for the batik product are IDR 82,500-IDR 66,000; chips Rp7,620-Rp6,336; and leather shoes Rp.103,800-Rp82,200.
\end{abstract}

Keywords: dual-channel supply chain; mathematical model; online pricing; small medium enterprise

\section{Introduction}

Dolly was the largest prostitution complex or brothel in Southeast Asia, located in the city of Surabaya, East Java, Indonesia. Since 2014, the Surabaya City Government has closed the prostitution complex and transformed the area into a center for Small and Medium Enterprises (SMEs). This transformation was welcomed positively because the Surabaya City Government not only closed it arbitrarily but also introduced a solution to keep the economy of the residents in the ex-localization area moving forward. The guidance carried out by the Surabaya City Government has succeeded in encouraging the emergence of various SME products from exlocalization ranging from handicraft products, food processing, to fashion products (Dinas Komunikasi dan Informatika Provinsi Jawa Timur, 2018).

One of the common problems faced by SMEs is the pricing decision for their products (Wattimena et al., 2020). The owners of SMEs often do not have a clear basis in determining the price of their products (Carson et al., 1998). Careless or intuitive pricing can increase the risk of disruption to the

\footnotetext{
*Correspondence Author

E-mail: ivangunawan@ukwms.ac.id
}

financial liquidity of SMEs and affect product marketing. Therefore, we need a correct pricing strategy approach to assist SMEs in the ex-localization of Dolly.

Apart from pricing issues, SMEs also experience difficulties in product marketing due to limited product marketing channels. Marketing channels currently used by SMEs are through physical stores or offline stores, with a very limited market reach. Moreover, Dolly's ex-localization location is also not a strategic place in Surabaya. SMEs need to consider a new sales channel known as an online channel (echannel) to expand their marketing reach. Along with the increasingly massive use of the internet, sales through online channels have been able to increase average sales by up to $20 \%$ (Widodo et al., 2014). Several options in developing this online channel include independent online stores, marketplaces, or social media. However, to start an independent online store requires investment costs and the ability to self-manage the website that SMEs in ex-localization do not yet have. Therefore, feasible online channels for ex-localized SMEs are through marketplaces or social media, which does not require a large investment to start. Various options of marketplaces and social media that exist today are the next problems. SMEs could not be able to manage all existing marketplaces and social media with their current resources. Therefore, it is 
necessary to identify the most popular marketplace and social media used by customers in buying products through the online channel. In this research, the questionnaire survey method was used as the means to understand the overview of what marketplaces or social media are widely used by the potential market for SME products to design an effective marketing strategy for online channels.

SMEs that have both offline and online sales channels face more complex pricing strategy problems. The concept of parallel selling via offline (conventional store) and online sales channels is known as the Dual-Channel Supply Chain (DCSC) (Widodo et al., 2014). Research focuses on pricing strategy for DCSC shows a positive increasing trend. The development of business models such as financing support schemes by eretailers (Yan et al., 2020) and product-service systems (Widodo et al., 2020) has become a strain of developments in pricing strategy research at DCSC. Issues faced by the industry such as disruption of demand (Huang et al., 2012); disruption of production costs (Huang et al., 2013); disruption of supply chain channels (Heydari et al., 2020), to the impact of industrial activities on the environment ( $\mathrm{Li}$ et al., 2016; Januardi et al., 2020) has also become a separate challenge in this research field. To examine the applicability of the pricing model at DCSC, Widodo (2014) compared three types of products: tickets, smartphones, and fashion that represent different levels of consumer acceptance towards their sales via online channels. Even though the development of pricing strategy research at DCSC is fast, the complexity of pricing at DCSC for SME products in Dolly's ex-localization could fill the population gap that exists in the research field. This research will involve three types of SMEs to represent SMEs in the ex-localization of Dolly. The three SMEs are an SME that produces batik to represent handicraft products, an SME that produces cassava chips to represent processed food products, and an SME that produces shoes to represent fashion products. Furthermore, this study aims to assist SMEs in the ex-localization of Dolly in determining potential online channels and setting optimal prices at DCSC. The theoretical contribution of this research is the involvement of empirical data obtained through questionnaires and interviews to verify the pricing model in the established DCSC. Eventually, the results of this study can be used directly as a recommendation for the pricing decision of SME products.

\section{Methods}

This research is divided into two stages. The first stage is a survey through questionnaires and interviews to obtain empirical data. It is then analyzed and used in experiments utilizing a mathematical model of pricing in DCSC to get analytical solutions.

\section{Survey}

The questionnaire survey method was used as the means to understand information related to marketplaces and social media which are widely used by potential markets in the online channel. Besides, the survey also includes questions about the sales channel preferences for each product, which then could be used as a parameter in the experiment using a mathematical model.
Questionnaires are distributed online via google form and offline by asking the respondent to fill it. The questionnaire contains 15 questions divided into three sections, which are respondent profiles, online transactions by respondents, and general information about SMEs under study. The number of respondents is determined by calculating the sample size based on proportions following equation (1) (Cochran, 2007).

$$
n=\frac{Z^{2} \cdot p \cdot(1-p)}{d^{2}}
$$

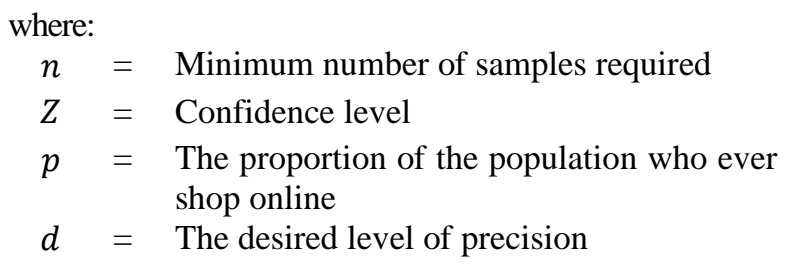

The proportion of the population who ever shop online is obtained from the results of a survey in 2017 which stated that $71 \%$ of residents of the city of Surabaya have made online shopping (Hamdi, 2017). The $\mathrm{Z}$ value is 1.96 for the $95 \%$ confidence interval. Thus, using equation (1), the minimum sample size is 317 people.

$$
n=\frac{1.96^{2} \cdot 0,53 \cdot 0,47}{0.05^{2}}=316.39
$$

The data obtained through a questionnaire is then visualized with an appropriate diagram and used to answer what is the proposed online sales channel for SMEs in the exlocalization of Dolly.

\section{Experiments}

The model proposed by Huang et al. (2013) is used for the experiment to find the best pricing scenario in DCSC. It is shown in equations (2) and (3) as follow:

$$
\begin{aligned}
& \text { Offline demand function } \\
& \qquad \boldsymbol{D}_{\boldsymbol{r}}=(\mathbf{1}-\boldsymbol{\rho}) \boldsymbol{a}-\boldsymbol{\alpha}_{\mathbf{1}} \boldsymbol{P}_{\boldsymbol{r}}+\boldsymbol{\beta}_{\mathbf{1}} \boldsymbol{P}_{\boldsymbol{d}}
\end{aligned}
$$

Online demand function

$$
D_{d}=\rho a-\alpha_{2} P_{d}+\beta_{2} P_{r}
$$

where:

$$
\begin{aligned}
& D_{r}=\text { offline (retail) channel demand } \\
& D_{d}=\text { online (direct) channel demand } \\
& a=\text { the forecasted potential demand if the } \\
& \text { products are free of charge } \\
& \rho=\text { the share of the demand goes to the online } \\
& \text { (direct) channel } \\
& P_{r} \quad=\text { offline (retail) } \text { channel price } \\
& P_{d}=\text { online (direct) channel price } \\
& \alpha \quad \text { the coefficients of self-price elasticity of } \mathrm{D}_{\mathrm{r}} \\
& \text { and } D_{d} \\
& \beta \quad \text { the coefficients of cross-price elasticity of } \\
& \mathrm{D}_{\mathrm{r}} \text { and } \mathrm{D}_{\mathrm{d}}
\end{aligned}
$$
pricing strategy with the presence of a parameter $\boldsymbol{\rho}$ which indicates consumer preferences in selecting sales channels 


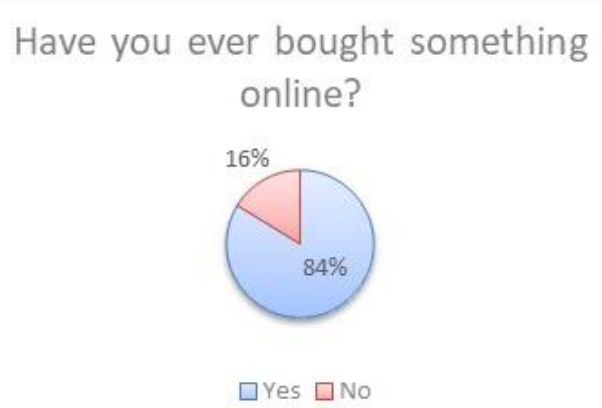

Figure 1. Percentage of Respondents Who Have Shopped Online

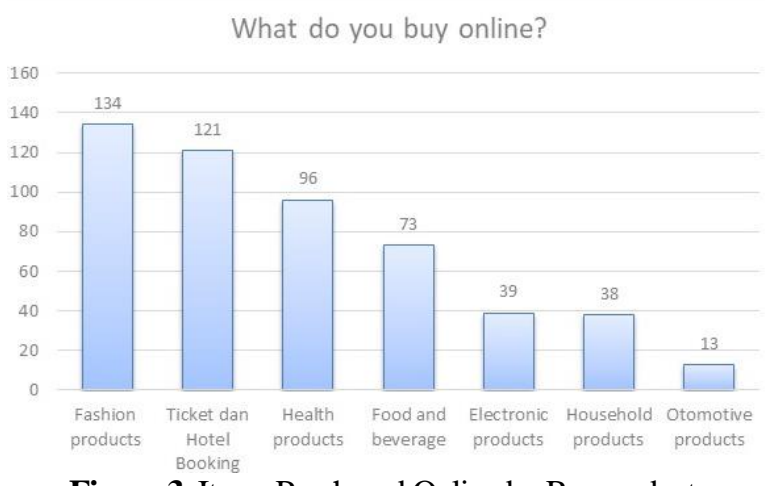

Figure 3. Items Purchased Online by Respondents

based on the type of product (Hinterhuber et al., 2012). Data for the model parameters were obtained through unstructured interviews with owners of SMEs and for parameter $\boldsymbol{\rho}$ obtained from questionnaires.

The pricing scenario proposed in this study is the Stackelberg leader-follower game as in Zhang et al. (2015). In this scenario, one channel is designated as the price leader by assuming the other channels would behave as the price followers. The price leader will determine its pricing strategy, then followed by the price follower. In this research, the existing offline channel will become the price leader. The pricing strategy for the offline channel has been set by the SME owners using the cost-based pricing strategy. Furthermore, the search for optimal solutions is carried out using Lingo 11 software. The assumption in this study is that products are always available for both channels, demand is only influenced by price, and demand is deterministic.

\section{Result and Discussion Respondent Profile}

The total number of respondents involved in the survey was 326 respondents. Among them, 227 respondents filled out questionnaires online and 119 respondents filled out the paperbased questionnaire that was distributed directly. As many as 20 questionnaires that were distributed directly were not filled in completely by the respondents, so only 99 data from respondents who filled out the paper-based questionnaire were used. This number has exceeded the minimum sample size of 317 people. The profile of 326 respondents is $62.9 \%$ are female respondents and the remaining $37.1 \%$ are male. The age range of $61 \%$ of respondents was between $17-25$ years old. Whereas

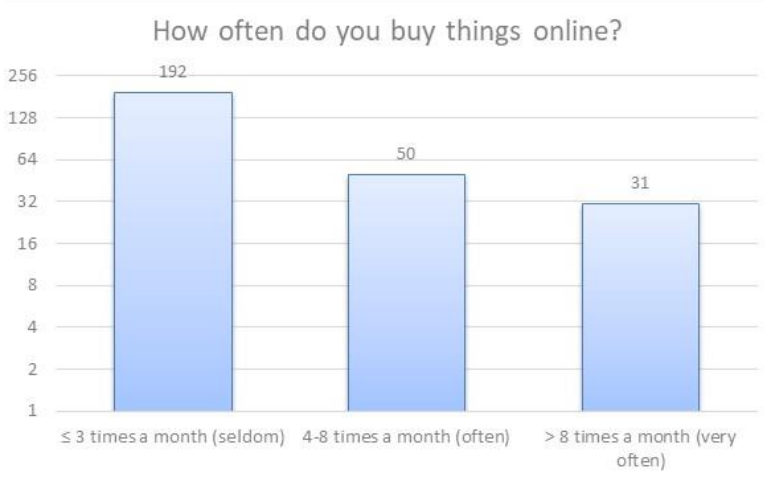

Figure 2. The Intensity of Online Shopping

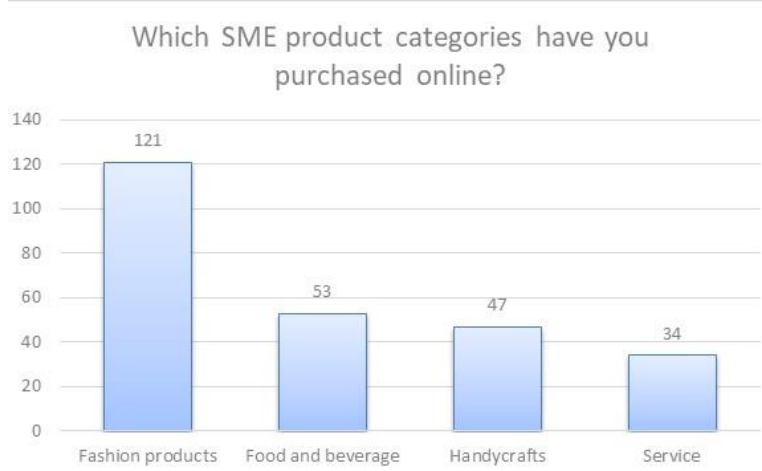

Figure 4. Type of Smes Products Bought by Respondents

$32.6 \%$ were over 25 years old and $6.4 \%$ of respondents were under 17 years old. The majority of respondents' occupations are $55.2 \%$ as students, $17.8 \%$ as private employees, the rest respectively are civil servants, housewives, and entrepreneurs. The results also show that $59 \%$ of respondents have a high school education background, $24 \%$ are undergraduate, the remaining $9 \%$ and $8 \%$ are diplomae and junior high school. Also, $30.4 \%$ of respondents are resided in East Surabaya, $20.9 \%$ in West Surabaya, $17.2 \%$ in North Surabaya, $16 \%$ in Central Surabaya, and the remaining $15.6 \%$ in South Surabaya.

\section{Online Shopping Behavior}

Amongst 326 respondents, $84 \%$ or 273 respondents admitted to ever having shopped online. Out of 273 respondents, 192 respondents are not consumers who do online shopping regularly. Research shows that 50 respondents said that they shop online 1-2 times a week and 31 respondents shop online more than 2 times a week. As can be seen in Figure 1 and Figure 2.

As can be seen in Figure 3 and Figure 4, fashion products, ticket and hotel bookings, and health products are the top three product categories purchased by consumers through the online channel. Most of the fashion and food and beverage products purchased through online channels are SME products.

Figure 5 shows that $58 \%$ of online consumers actively shop online through e-commerce platforms, marketplaces, or social media. However, the number of consumers who shop through the marketplace alone is more than the number of consumers who shop through social media. The marketplace has the advantage of being able to compare the price and goods to be purchased. Moreover, the purchasing transaction through 


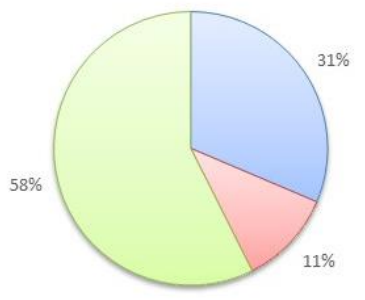

aMarketplace $\square$ Social media $\square$ Both

Figure 5. The Platform Chosen by Respondents to Shop Online

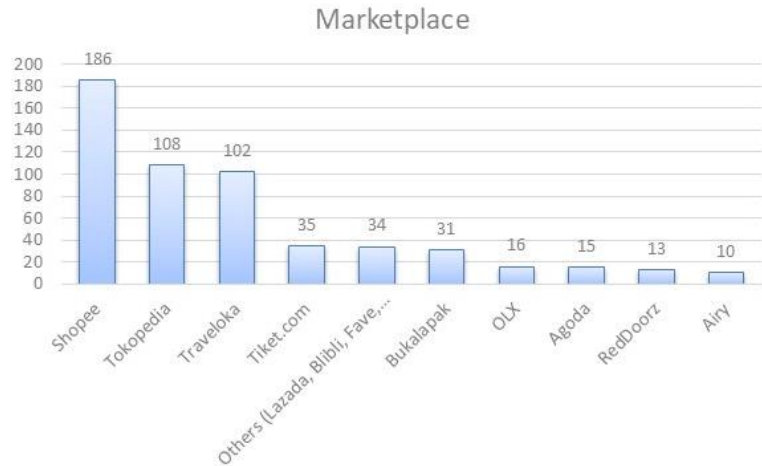

Figure 6. Marketplace Used by Respondents

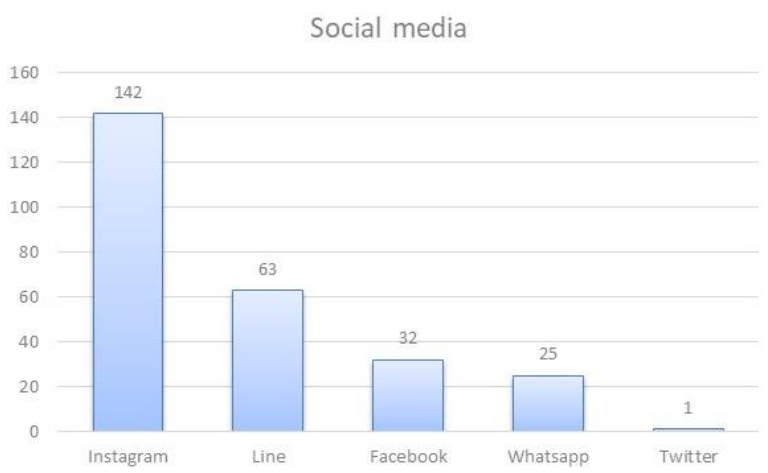

Figure 7. Social Media Selected by The Respondent

Table 1. Consumer Preference in Buying A Product Through Online Channels

\begin{tabular}{cccc}
\hline & Batik & Chips & Leather shoes \\
\hline$\rho$ & 0.498 & 0.582 & 0.465 \\
\hline
\end{tabular}

Table 2. The Confidence Interval $P$ for Each Product

\begin{tabular}{cccc}
\hline & Batik & Chips & Leather shoes \\
\hline$\rho$ & $0.498 \pm 0.054$ & $0.582 \pm 0.053$ & $0.465 \pm 0.054$ \\
\hline
\end{tabular}

the marketplace is safer than through social media Therefore, SMEs are advised to open online sales channels through both the marketplace and social media. However, considering the resource constraints, it is suggested that SMEs should begin their online channel business through the marketplace.

Shopee, Tokopedia, and Traveloka are the top 3 marketplaces that are most popular with online consumers (see Figure 6 and Figure 7). Of the 273 respondents who shop online, 186 admitted to using Shopee, 108 admitted to using Tokopedia, and 102 buying tickets and booking hotels using Traveloka. Therefore, SMEs can choose to use Shopee or Tokopedia as an alternative to starting online channels through the marketplace. The social media that is considered the most favorite for online consumers is Instagram. 142 out of 153 respondents who use social media to shop online chose Instagram as the most supportive social media platform for online shopping.

The parameter $\rho$ which will be used in the pricing model at DCSC is obtained through questionnaire questions 14 to 16 (see Appendix). The proportion of respondents who prefer online channels for the three SME products can be seen in Table 1. Next, the confidence interval is calculated for $\rho$ of each product with the equation (4)

$$
\rho \pm z \cdot \sqrt{\frac{\rho(1-\rho)}{n}}
$$

With a $95 \%$ confidence level, the $z$ value is 1.96 and the sample size (n) is 326 respondents, then the confidence interval for the value of $\rho$ is obtained as can be seen in Table 2 .

\section{Pricing Strategy for three products at DCSC for SMEs in the ex-localization of Dolly}

Three SMEs whose products are the subject of this research is the KBU Mampu Jaya: leather shoes, Samijali: similar chips, and Alpujabar: batik. Parameter $a$ in this study employing information about the production capacity in one month, which is assumed to run out if the SME has two sales channels. Thus, potential demand is fulfilled based on maximum capacity production. The production cost per unit $\left(\mathrm{C}_{\mathrm{u}}\right)$ is obtained by calculating the total production cost for one month divided by the production capacity. Table 3 shows the parameters used in the mathematical model. The limitation in pricing strategy for SME products is that pricing does not consider interactions with the product mix produced by these SMEs. 
Table 3. Model Parameters Based on Data Obtained from SME Owners

\begin{tabular}{llll}
\hline Parameter & Batik & Chips & Leather shoes \\
\hline$a$ & 500 pieces & 1,800 packs & 1,350 pairs \\
$P_{r}$ (Rp/unit) & 150,000 & 12,000 & 200,000 \\
$C_{u}$ (Rp/unit) & 59,250 & 5,500 & 111,300 \\
\hline
\end{tabular}

Table 4. The Parameter Values $\alpha_{1}, \alpha_{2}, \beta_{1}$, And $\beta_{2}$

\begin{tabular}{clll}
\hline Parameter & Batik & Chips & Leather shoes \\
\hline$\alpha_{1}$ & 0.00017 & 0.0008 & 0.0002 \\
$\alpha_{2}$ & 0.000375 & 0.0012 & 0.00036 \\
$\beta_{1}=\beta_{2}$ & 0.00025 & 0.001 & 0.00027 \\
\hline
\end{tabular}

Table 5. The Solution of Pricing Decision of Each Product for DCSC Using the Proposed Model

\begin{tabular}{llll}
\hline & Batik & Chips & Leather shoes \\
\hline Profit (Rp) & $26,152,510$ & $6,433,605$ & $50,879,490$ \\
$P_{d}$ (Rp/ unit) & 74,700 & 6,984 & 93,000 \\
Range of $\mathrm{P}_{\mathrm{d}}(\mathrm{Rp} /$ unit) & $82,500-66,000$ & $7,620-6,336$ & $103,800-82,200$ \\
\hline
\end{tabular}

The parameters $\alpha_{1}$ and $\alpha_{2}$ show the price elasticity of demand on their respective channels. $\alpha_{1}$ shows the offline price elasticity to demand on the offline channel and $\alpha_{2}$ shows the online price elasticity on the online channel. The values of $\alpha_{1}$ and $\alpha_{2}$ convert the price into demand. If $\alpha_{1}$ and $\alpha_{2}$ show price elasticity towards their channel, $\beta_{1}$ and $\beta_{2}$ show cross-price elasticity: offline price against online demand and online price against offline demand. The assumptions in this study for the parameters $\beta_{1}$ and $\beta_{2}$ are that the effect of the cross-price is symmetrical or the effect of online prices on offline demand and the effect of offline prices on online demand is the same so that $\beta_{1}=\beta_{2}$.

The values of $\alpha_{1}, \alpha_{2}, \beta_{1}$, and $\beta_{2}$ in this study were obtained by conducting trial and error using a validated spreadsheet with the opinion of the SMEs owner based on their expertise in judgment. Thus, the parameter values $\alpha_{1}, \alpha_{2}, \beta_{1}$, and $\beta_{2}$ are obtained and shown in Table 4.

The general profit is calculated by equation (5)

$$
\text { Profit }=\text { Demand } \mathrm{x} \text { (Price }- \text { Cost })
$$

Thus, when combined with equations (2) and (3) it will become equations (6) and (7)

$$
\begin{aligned}
& \text { Profit }=D_{r} \cdot\left(P_{r}-C_{u}\right)+D_{d} \cdot\left(P_{d}-C_{u}\right) \\
& \text { Profit }=\left((1-\rho) a-\alpha_{1} P_{r}+\beta_{1} P_{d}\right)\left(P_{r}-C_{u}\right) \\
& +\left(\rho a-\alpha_{2} P_{d}\right. \\
& \left.+\beta_{2} P_{r}\right)\left(P_{d}-C_{u}\right)
\end{aligned}
$$

The solution to the model is done by transforming equation (7) into linear programming equations to maximize profits. Therefore, the objective function is to maximize profit at DCSC as shown by equation (8).

$$
\begin{aligned}
\text { Max Profit }=( & \left.(1-\rho) a-\alpha_{1} P_{r}+\beta_{1} P_{d}\right)\left(P_{r}\right. \\
& \left.-C_{u}\right)+\left(\rho a-\alpha_{2} P_{d}\right. \\
& \left.+\beta_{2} P_{r}\right)\left(P_{d}-C_{u}\right)
\end{aligned}
$$

Under normal conditions, online channels can make sales if $P_{r} \geq \frac{P_{d}}{\rho}$ (Widodo et al., 2011). This requirement then becomes the constraint function used in the linear programming equation in equation (10).

$$
\begin{aligned}
& P_{r} \geq \frac{P_{d}}{\rho} \\
& P_{d}>0
\end{aligned}
$$

This constraint function mathematically shows that online sales can occur if $P_{d}$ has reached its threshold value. Then, equation (10) is the nonnegative constraint. The solution of the proposed mathematical model can be seen in Table 5 .

The mathematical model has been successful in providing solutions to proposed online pricing decisions for three products: batik, chips, and leather shoes. The range of $P_{d}$ is identified by changing the proportion of sales through online channels as in Table 2 . The difference between online prices, offline prices, and production costs can be seen in Figure $\mathbf{8}$, Figure 9, and Figure 10. Figure 8, Figure 9, and Figure 10 show that the online price decision for batik and chips is still feasible because it is above the production cost. However, the online price for leather shoes is no longer feasible because it is below production costs. Therefore, SME owners must reduce production costs or increase the value of $\rho$ so that the leather shoes become feasible to be sold through online channels. Increasing the value of $\rho$ can be done through advertising on social media, providing or creating interesting content on social media so that consumer preferences for buying leather shoe products through online channels can increase. Based on the model, the online price for leather shoe products would be feasible if the value of $\rho$ is above 0.57 (see Figure 11).

\section{Conclusion}

The survey results have presented several alternatives of online channels that SMEs in the ex-localization of Dolly can choose from. Marketplace: Shopee and Social media: Instagram can be used as an alternative to market their products through online channels. Furthermore, the mathematical model proposed by Huang et al. (2013) and Widodo et al. (2011) has successfully assisted SMEs in the ex-localization of Dolly in the pricing decision of products sold through the online channel. The pricing model at DCSC provides insights for SMEs to decide prices rationally. For batik, the selling price through the proposed online channel is between IDR 82,500-IDR 66,000. Whereas, for chips product, the price between Rp. 7,620 - Rp. 6,336 is feasible for sales via the online channel. However, the price for leather shoes, which is the optimal solution for the 


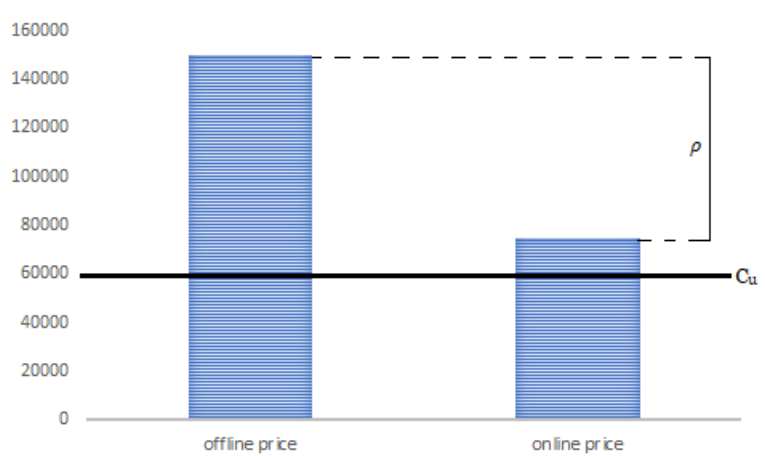

Figure 8. Comparison of Online Prices, Offline Prices, And Production Costs for Batik Products

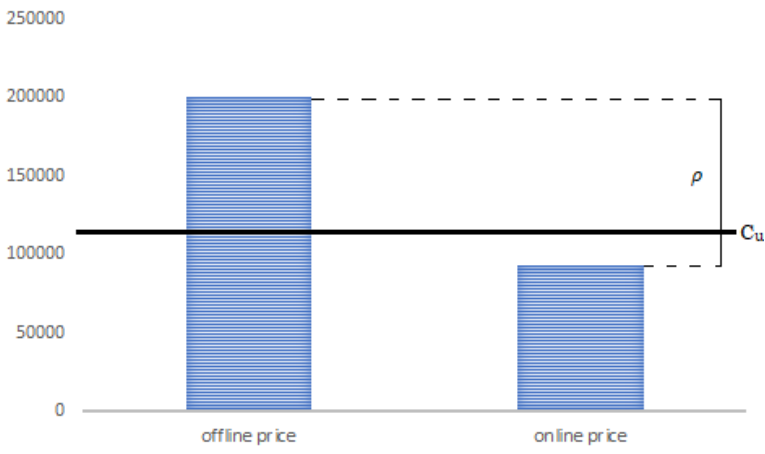

Figure 10. Comparison of Online Prices, Offline Prices, And Production Costs for Leather Shoe Products

model, turns out to be below the cost of production because consumer preferences for buying leather shoes produced by SMEs are still low. Therefore, it is proposed that SMEs need to carry out promotions through online media to increase consumer preferences for buying leather shoes through online channels.

Subsequent research proposals are to explore why consumer acceptance of the online sales channel for leather shoe products is low and how to increase consumer acceptance for the online sales channel of leather shoe products. The limitation of this research is the lack of exploration on consumer behavior on SME's products in Dolly. Further research that focuses on consumer behavior towards SMEs in Dolly should be done to enrich the field of study. In addition, the model solution has not taken into account the product mix of SMEs in Dolly. A further research proposal for the pricing model at DCSC should involve the product mix phenomenon that exists in a business.

\section{References}

Carson, D., Gilmore, A., Cummins, D., O’Donnell, A., \& Grant, K. (1998). Price Setting in SMEs: Some Empirical Findings. Journal of Product \& Brand Management, 7(1), 74-86.

Cochran, W. G. (2007) Sampling Techniques, $3^{\text {rd }}$ ed. Hoboken: John Wiley \& Sons.

Dinas Komunikasi dan Informatika Provinsi Jawa Timur. (2018). Eks Lokalisasi Dolly Kini Miliki 23 Kelompok UKM. Retrieved from: http://kominfo.jatimprov.go.id/read/umum/ekslokalisasi-dolly-kini-miliki-23-kelompok-ukm-.

Hamdi, I. (2017) Riset Google: Warga Surabaya Paling Banyak Belanja Online. Retrieved from:

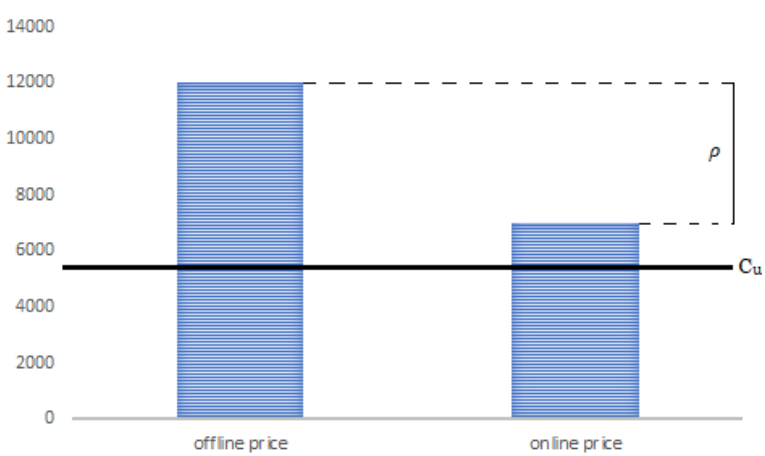

Figure 9. Comparison of Online Prices, Offline Prices, And Production Costs for Chip Products

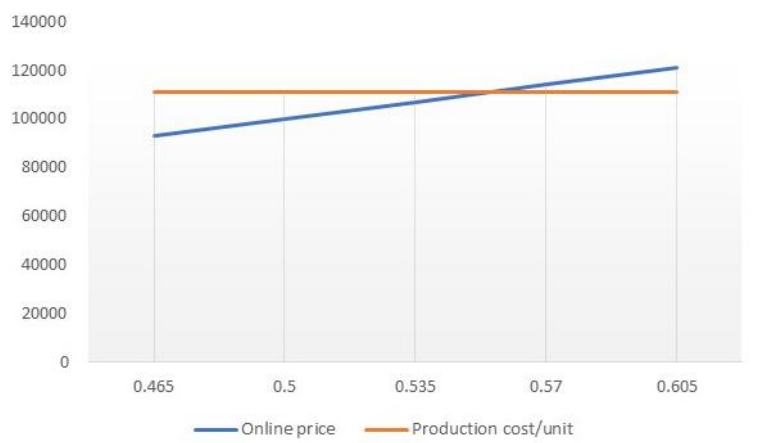

Figure 11. Sensitivity Analysis of Online Prices for Leather Shoe Products to the Value of $\rho$

https://bisnis.tempo.co/read/900135/riset-googlewarga-surabaya-paling-banyak-belanjaonline/full\&view=ok.

Heydari, J., Aslani, A., \& Sabbaghnia, A. (2020). A Collaborative Scenario-based Decision Model for a Disrupted Dual-Channel Supply Chain: Benchmarking against the Centralized Structure. Benchmarking: An International Journal, 27(3), 993-957.

Hinterhuber, A. \& Liozu, S. (2012). Is it time to Rethink Your Pricing Strategy?, MITSloan Management Review.

Huang, S., Yang, C., \& Zhang, X. (2012). Pricing and Production Decisions in Dual-Channel Supply Chains with Demand Disruptions. Computers \& Industrial Engineering, 62(1), 70-83.

Huang, S., Yang, C., \& Liu, H. (2013). Pricing and Production Decisions in a Dual-Channel Supply Chain when Production Costs are Disrupted. Economic Modelling, 30, 521-538.

Januardi, J., \& Widodo, E. (2020). Response Surface Methodology of Dual-Channel Green SupplyChain Pricing Model by Considering Uncertainty. Supply Chain Forum: An International Journal, 22(1), 16-27.

Li, B., Zhu, M., Jiang, Y., \& Li, Z. (2016). Pricing Policies of a Competitive Dual-Channel Green Supply Chain. Journal of Cleaner Production, 112, 2029-2042.

Wattimena, K. T. \& Irmansyah. (2020). Kesalahan Penetapan Harga oleh Usaha Mikro Kecil Menengah yang Menyebabkan Kesulitan Likuiditas. Jurnal Pendidikan Akuntansi dan Keuangan, 8(1), 15-23. 
Widodo, E. (2014). Penetapan Harga Berbasis Penerimaan Konsumen di Dual-Channel Supply Chain, Jurnal Teknik Industri, 15(1), 1-8.

Widodo, E., Pujawan, I. N., Santosa, B., Takahashi, K., \& Morikawa, K. (2013). Adjusted-Stackelberg Scheme in Applying Profit-sharing to Coordinate Dual Channel Supply Chain. Asian Journal of Management Science and Applications, 1(1), 5066.

Widodo, E., Shabir, I. N. A., \& Syairudin, B. (2020) Pricing for Product-Service System under DualChannel Supply Chain. In AIP Conference Proceedings, 2217(1), 030036-1-030036-8.

Widodo, E., Takahashi, K., Morikawa, K., Pujawan, I. N., \& Santosa, B. (2011). Managing Sales Return in Dual Sales Channel: Its Product Substitution and Return Channel Analysis. International Journal of Industrial and Systems Engineering, 9(2), 121-149.

Yan, N., Liu, Y., Xu, X., \& He, X. (2020). Strategic DualChannel Pricing Games with e-retailer Finance. European Journal of Operational Research, 283(1), 138-151.

Zhang, C., Gu, B., Yamori, K., Xu, S., \& Tanaka, Y. A. (2015). Novel Stackelberg-Bertrand Game Model for Pricing Content Provider. In Proceedings of the 8th International Conference on Mobile Multimedia Communications (pp. 128-132).

\section{Appendix \\ Research Questionnaire \\ Product Pricing for Online Market}

Hello! We are currently researching pricing for products marketed online. It aimed to help SMEs in the city of Surabaya. Besides being able to assist in pricing, it is hoped that encouraging marketing products online can make the SMEs' products known by the wider community.

Hereby, we request your time to fill out the questionnaire below. All information will be kept confidential.

* Required

\section{A. Questions about Yourself}

Instructions for filling out: Answer the questions below correctly

1. Full Name *

$\begin{aligned} & \text { 2. Gender } * \\ & \circ \text { Male } \\ & \circ \text { Female } \\ & \text { 3. Age } * \\ & \circ<17 \text { Years } \\ & \circ 17-25 \text { years old } \\ & \circ 26-35 \text { years old } \\ & \circ 36-45 \text { years old } \\ & \circ 46-55 \text { years old } \\ & \circ 55 \text { years old }\end{aligned}$

4. Last Education *

- Elementary school

○ Junior high school

- Senior High School

- Undergraduate

o Others:

5. Job *

Civil Servants/BUMN/Military Officers

Self-employed

Employees/Private Employees

Students

Housewife

- Others:

6. Living Area in Surabaya City *

- Central Surabaya

- East Surabaya

- West Surabaya

- North Surabaya

- South Surabaya

B. Questions about Online Transactions

7. Have you ever shopped for products online? (if yes, continue to question no. 8-16). Otherwise you do not need to continue this questionnaire.*

○ Yes

○ Not

8. If yes, how often do you shop online?
- 3 times a month
- 4-8 times a month
- 8 times a month

9. When shopping online, what services do you usually use?

- Social media

- E-Commerce Application

○ Both

10. What social media do you use to make transactions? (may have more than 1 choice)
$\circ$ Instagram
- Facebook
- Twitter
- Line
o Others:

11. What e-commerce application do you use to make transactions? (may have more than 1 choice)
- Bukalapak
○ Tokopedia
- Shopee
- OLX
- Tiket.com
○ Agoda
- Traveloka
- RedDoorz
○ Airy
o Others:

12. What products do you usually buy online? (may have more than 1 choice)

○ Hotel Tickets and Vouchers (Airplane, Train, Bus, Hotel etc)

- Electronics (Television, Computers, etc)

- Home Appliances (Table, Fan, etc)

○ Fashion (Clothing, Shoes, Bags, etc) 
- Automotive (Car Wipes, Car Wash Soap, etc)

- Culinary (Snacks and the like)

- Health (Beauty Serum, Pharmacy, etc)

C. Questions about SMEs

12. Have you ever known SME's in Dolly area?

○ Yes

○ Not

13. What creative products from SMEs have you bought/used online? (May more than 1 choice)

- Crafts (Batik Fabrics, Handmade Bags, Home Decorations)

- Fashion (Clothes, Shoes, Pants)

- Culinary (Snacks: Chips, Dry Bread, Nuts, Milk Pie)

- Services (Design, Photos, Advertising)
14. If there are creative SME Fashion products (Shoes) you prefer to buy these products through? (assuming the online shop is cheaper)

- Offline (conventional) shop

- Online shop

15. If there are creative SME handicraft products (Batik cloth) you prefer to buy these products through? (assuming the online shop is cheaper)

$$
\circ \text { Offline (conventional) shop }
$$

o Online shop

16. If there are creative products from SMEs, snacks (chips) you prefer to buy these products

through? (assuming the online shop is cheaper)

$$
\circ \text { Offline (conventional) shop }
$$

- Online shop

Thank you for your time to fill out the questionnaire. 